\title{
PREVALENSI KELUHAN MUSKULOSKELETAL DAN KELUHAN KESEHATAN LAINNYA PADA PEKERJA PURA BATU PADAS DI DESA TAMBLANG DALAM KONSEP HEALTH ERGONOMIC
}

\author{
Putu Sukedana ${ }^{1}$, Luh Made Indah Sri Handari Adiputra ${ }^{2}$ \\ ${ }^{1}$ Program Studi Pendidikan Dokter, ${ }^{2}$ Bagian Fisiologi \\ Fakultas Kedokteran Universitas Udayana \\ Email: luhmadeindah@yahoo.com
}

\begin{abstract}
ABSTRAK
Pulau Bali merupakan pulau yang dikenal sebagai pulau seribu pura. Pekerja pembuat pura harus memotong batu yang keras dan merakitnya. Keluhan muskuloskeletal sering dialami oleh pekerja.Tujuan dari penelitian ini adalah untuk mengetahui gambaran keluhan otot pada pekerja pura batu padas di Desa Tamblang.

Penelitian ini adalah penelitian cross sectional dan hasilnya dianalisis secara deskriptif. Jumlah responden 32 orang yang terdiri dari perakit dan pemotong batu pura batu padas di Desa Tamblang. Responden diminta untuk mengisi kuesioner Nordic Body Map.

Keluhan muskuloskeletal pada perakit batu sering dirasakan di bagian pinggang $75 \%$, persendian siku kanan dan kiri 45,8\%, bahu kiri dan kanan 41,7\%, dan pergelangan tangan 37,5\%. Pada alat gerak bawah sering mengalami keluhan pada bagian lutut $29,2 \%$, betis $12,5 \%$, dan pergelangan kaki $25 \%$. Keluhan muskuloskeletal pada pemotong batu terjadi pada pinggang, lengan atas, bahu, leher atas dan bawah, siku, dan punggung. Pada alat gerak bawah pemotong batu sering mengalami keluhan pada lutut $62,5 \%$, betis $62,5 \%$, pergelangan kaki 50\%. Keluhan responden dominan pada siku, pergelangan tangan, dan pinggang untuk bagian tubuh di atas bokong. Sedangkan untuk keluhan otot di bawah bokong dominan sering dirasakan pada lutut dan pergelangan kaki.

Keluhan lain pada pekerja seperti pada sistem pernapasan, saraf, dan lain-lain yaitu : pada perakit batu sebanyak 15,6\% responden menyatakan sesak, pemotong batu $6,25 \%$. Keluhan nyeri hidung dialami oleh perakit batu sebanyak 3,1\%. Pemotong batu mengalami keluhan kebas sebanyak $6,25 \%$. Keluhan lainnya seperti kelilipan pada mata dan nyeri pada dada. Keluhan ini dialami hanya pada perakit batu sebanyak $6,25 \%$.
\end{abstract}

Kata Kunci: Keluhan Muskuloskeletal, Masalah Kesehatan, Pekerja Pura Batu Padas, Health Ergonomic 


\title{
THE PREVALENCE OF MUSCULOSKELETAL AND OTHER HEALTH COMPLAINTS AMONG TEMPLE BUILDERS AT TAMBLANG VILLAGE BASED ON HEALTH ERGONOMICS CONCEPT
}

\begin{abstract}
Bali is known as the island of a thousand temples. Temple builders had to cut hard rock and assemble them. Musculoskeletal complaints often experienced among the workers. The purpose of the study was to find out the prevalence of musculoskeletal complaints on the temple builders at Tamblang Village.

This research was using a cross-sectional study and the results were analyzed descriptively. Respondents were 32 temple builders as assemblers and stonecutter at Tamblang Village. Respondents were requested to filled Nordic Body Map questionnaire.

The result showed that musculoskeletal complaints on assemblers are on the waist $75 \%$, right and left elbow joints $45.8 \%$, right and left shoulder $41.7 \%$, and wrist $37.5 \%$. Musculoskeletal complaints on locomotor are on knee $29.2 \%$, calf $12.5 \%$ and ankle $25 \%$. Musculoskeletal complaints on stonecutter are on the waist, arm, shoulder, neck, elbow, and back. Musculoskeletal complaints on locomotor are on knee $62.5 \%$, calf $62.5 \%$, and ankle $50 \%$. Most of respondents complaint about elbow, wrist, waist, knee, and ankle.

Other complaint on temple builders is on the respiratory system, nervous system, and others. $15.6 \%$ of assemblers said tightness, and $6.25 \%$ of stonecutter. The nose complaint on assemblers is $3.1 \%$. The numbness complaint on stone cutter is $6.25 \%$. Other complaint is on the eye and chest, experienced only on assemblers as much as $6.25 \%$ of respondents.
\end{abstract}

Key Words: Musculoskeletal Complaints, Health Problems, Temple Makers, Health Ergonomic 


\section{PENDAHULUAN}

Pulau Bali merupakan pulau yang dikenal sebagai pulau seribu pura. Pura merupakan tempat sembahyang umat Hindu. Mayoritas warga Bali beragama Hindu. Hal ini didukung dari hasil sensus Badan Pusat Statistik tahun 2010 yaitu jumlah umat Hindu di Bali mencapai 3,2 juta penduduk dari 3,89 juta total penduduk di Bali. Menurut kitab Tantra Samuscaya I. 1. 28, disebutkan bahwa pura dibangun di tempattempat yang dianggap suci seperti patirtaan (tempat keluarnya air yang dianggap suci oleh umat Hindu), tepi sungai, dan tepi pantai dengan berbagai syarat (Makiyah, 2007).

Berdasarkan catatan Departemen Agama Provinsi Bali tahun 2011, jumlah pura Kahyangan Tiga (Pura Dalem, Pura Puseh, Pura Bale Agung) di Bali mencapai 4.356 buah, 723 buah pura Kahyangan Jagat, dan 923 buah pura Swagina atau pura Kawitan atau pura panyungsungan keluarga. Jumlah pura di Bali meningkat seiring pertumbuhan penduduk Bali yang terus berkembang. Akan tetapi, tingkat pengangguran tahun 2010 di Bali mencapai 2,85 persen (Badan Pusat Statistik Prov. Bali, 2010). Dengan tingginya kebutuhan umat Hindu akan bangunan pura, maka membuka mata pencaharian baru bagi masyarakat Bali untuk menjadi pekerja pembuat pura untuk meningkatkan kesejahteraan masyarakat.

Bangunan pura di Bali biasanya terbuat dari bata merah, batu padas, kayu, campuran semen dan pasir atau bambu (Maharlika, 2010). Dari segi ketahanan terhadap perubahan cuaca dan menahan beban, batu padas memiliki daya tahan yang paling kuat. Bata merah lebih lemah dibandingkan batu padas dalam menahan beban namun lebih ringan dibandingkan batu padas. Kekuatan tekan rata-rata bata merah kelas 25 pada standar SII-0021-1978 hanya $25 \mathrm{~kg} / \mathrm{cm}^{2}$ (Indra, 2012). Kayu dan bambu juga lebih cepat lapuk dibandingkan dengan batu apabila terkena hujan. Pura yang terbuat dari batu tidak memerlukan atap sehingga dapat menghemat pembiayaan. Oleh karena itu, masyarakat saat ini mulai membuat pura dari bahan batu daripada dari bata merah, kayu, dan bambu khususnya dari batu padas.

Berdasarkan pengamatan langsung pada pekerja pura batu padas di Desa Tamblang, tampak adanya suatu sikap kerja yang tidak ergonomis seperti gerakan punggung yang terlalu membungkuk saat menyusun batu menjadi pura, postur kepala terlalu maju saat membentuk batu agar sesuai dengan yang diinginkan, dan posisi berdiri yang statis dalam waktu yang lama saat memotong batu (penebih). Postur kepala yang terlalu maju dalam bekerja akan diikuti nyeri leher nantinya (Nejati et al, 2014). Hal tersebut disebabkan oleh tuntutan tugas yang tidak sesuai dengan kemampuan dan keterbatasan pekerja. Terlebih saat mendekati adanya hari baik membangun pura (duasa melah). Pekerja pura batu padas memiliki ritme kerja yang berbeda dengan pekerja kantoran. Proses memotong batu hingga menyusun menjadi pura membutuhkan waktu yang tidak singkat. Permintaan yang meningkat pada hari-hari tertentu juga harus dipenuhi demi mendapatkan keuntungan.

Situasi kerja pada pekerja batu padas memang di bawah atap rumah, namun proses pemotongan batu (nebih) menimbulkan kebisingan dan memerlukan energi yang besar karena batu yang harus dipotong berukuran besar. Kebisingan di tempat kerja juga mempengaruhi kesehatan dan produktivitas pekerja. Kebisingan merupakan salah satu stresor lingkungan yang dapat mengganggu kesehatan seperti sistem kardiovaskuler, saraf, endokrin, dan pendengaran (Gannouni et al, 2014).

Sikap kerja adalah posisi kerja yang secara alamiah dibentuk oleh tubuh pekerja akibat berinteraksi dengan fasilitas yang digunakan ataupun kebiasaan kerja (Indira, 2014). Sikap kerja yang kurang sesuai dapat menyebabkan keluhan muskuloskeletal (Costa et al, 2010). Kausto et al, (2010) 
menyatakan bahwa keluhan muskuloskeletal adalah masalah kesehatan umum dan menjadi penyebab utama kecacatan seluruh dunia. Kerugian ekonomi akibat gangguan tersebut mempengaruhi tidak hanya individu tetapi juga organisasi dan masyarakat secara keseluruhan. Selain itu, penyakit ini merupakan alasan umum seorang pekerja untuk berhenti bekerja. Saat ini, keluhan muskuloskeletal adalah salah satu masalah ergonomi yang paling penting yang diperhatikan pada tempat kerja di seluruh dunia.

Menurut International Labor Organization (ILO), setiap tahun terjadi 1,1 juta kematian yang disebabkan oleh penyakit yang disebabkan oleh pekerjaan. Sekitar 300.000 kematian terjadi dari 250 juta kecelakaan dan sisanya adalah kematian karena penyakit akibat kerja dimana diperkirakan terjadi 160 juta penyakit akibat hubungan pekerjaan baru setiap tahunnya. Penyakit akibat pekerjaan tersebut yang paling banyak adalah keluhan muskuloskeletal (Buchari, 2007).

Tujuan dari penelitian ini adalah untuk mengetahui gambaran keluhan otot pada pekerja pura batu padas di Desa Tamblang dalam konsep Health Ergonomic.

\section{MATERI DAN METODE}

Populasi dalam penelitian ini adalah pekerja usaha pura batu padas yang berada di Desa Tamblang, Kecamatan Kubutambahan, Kabupaten Buleleng. Peralatan yang digunakan formulir data subjek dan kuesioner Nordic Body Map serta alat tulis untuk mencatat.

Penelitian ini merupakan cross sectional study. Responden terbagi menjadi dua kelompok yaitu responden perakit batu dan pemotong batu.

Pengambilan data dilakukan dengan cara memberikan kuesioner kepada pekerja pura batu padas yang sudah memenuhi kriteria inklusi dan eksklusi. Total responden yang diberikan kuesioner sebanyak 32 responden.

Hasil yang diperoleh dari Kuesioner Nordic Body Map diolah dan disajikan ke dalam bentuk tabel kemudian dianalisis secara deskriptif untuk mengetahui keluhan muskuloskeletal yang dialami oleh pekerja pura batu padas.

\section{HASIL DAN PEMBAHASAN}

\subsection{Karakteristik Responden}

Jumlah responden pada pekerja pura batu padas adalah 32 responden dengan 24 orang sebagai perakit batu dan delapan orang sebagai pemotong batu. Semua responden berjenis kelamin laki-laki yang berasal dari 10 desa seperti yang disajikan pada Gambar 1 .

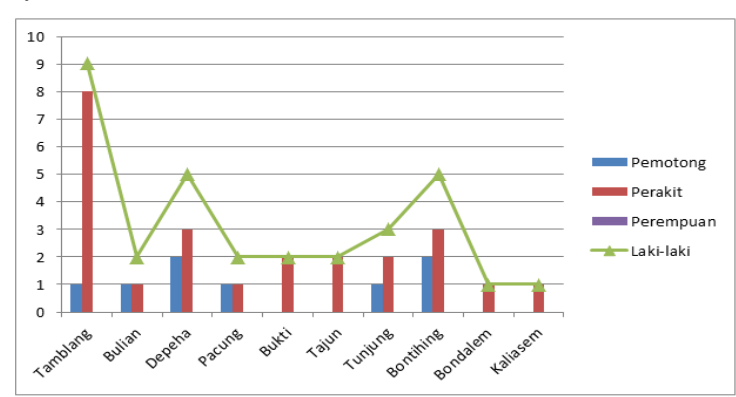

Gambar 1. Asal desa pekerja

Pekerja paling banyak berasal dari Desa Tamblang yaitu sebanyak sembilan orang dari 32 responden. Pekerja disini dibagi menjadi yang bertugas menjadi pemotong/penebih/tukang sensor (delapan responden) dan tukang akit/perakit (24 responden). Usia pekerja bervariasi dari umur 17-45 tahun dengan rerata umur pekerja 31 tahun. Tingkat pendidikan terakhir pekerja mulai dari Sekolah Dasar (SD) hingga Sekolah Menengah Atas (SMA).

3.2 Gambaran Keluhan Muskuloskeletal Pada Pekerja Pembuatan Pura Batu Padas Di Desa Tamblang 


\subsubsection{Posisi Tubuh Pekerja}

Pekerja pura batu padas pada dasarnya memiliki tiga posisi tubuh yang dilakukan, yaitu: posisi duduk, jongkok, dan berdiri. Akan tetapi, pekerja yang bertugas memotong batu posisi tubuhnya lebih dominan dalam posisi berdiri dibandingkan dengan perakit batu (Gambar 2).
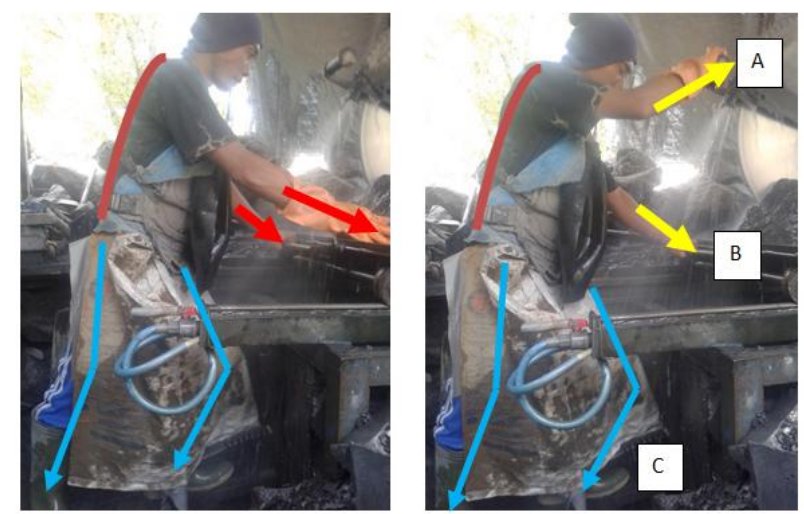

Gambar 2. Postur kerja pekerja pura batu padas saat berdiri

Pekerja pada perakit batu sering dalam posisi jongkok atau duduk. Posisi berdiri jarang dilakukan, hanya pada saat mengambil batu dari tempat pemotongan ke tempat perakitan batu (Gambar 3).
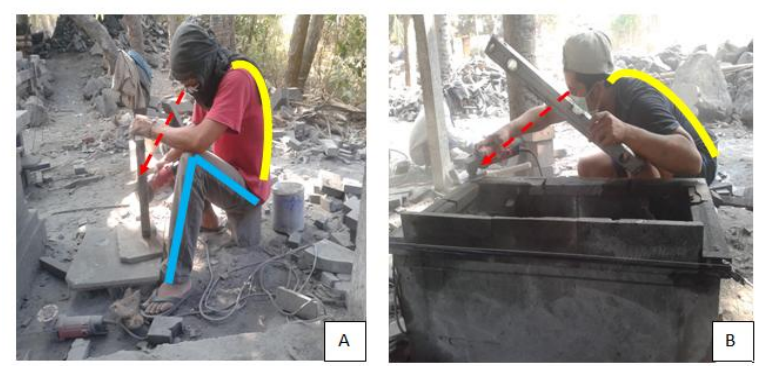

Gambar 3. Postur Kerja Perakit Batu Saat Jongkok Dan Duduk

\subsubsection{Keluhan Muskuloskeletal Pekerja Pura Batu Padas}

Keluhan muskuloskeletal pada perakit batu sering dirasakan di bagian pinggang $75 \%$, persendian siku kanan dan kiri 45,8\%, bahu kiri dan kanan $41,7 \%$; dan pergelangan tangan $37,5 \%$. Pada alat gerak bawah sering mengalami keluhan pada bagian lutut $29,2 \%$, betis $12,5 \%$, dan pergelangan kaki $25 \%$.

Dalam posisi menunduk atau condong ke depan otot-otot bagian pinggang mengalami kontraksi yang berulang dengan beban yang lebih berat. Jika posisi badan pekerja tegak sebenarnya otot pinggang tidak mudah lelah dan nyeri. Peran persendian siku sangat penting karena untuk memasang batu diperlukan posisi lengan yang lurus atau ditekuk. Saat lengan dalam posisi lurus, tangan membawa beban sehingga persendian di siku pun mendapatkan gaya ke arah atas untuk mengimbangi gaya gravitasi batu. Hal ini membuat siku sering sakit pada pekerja pura batu padas (Gambar 4).

Tabel 1. Distribusi Frekuensi Keluhan Muskuloskeletal Perakit Pura Batu Padas

\begin{tabular}{|c|c|c|c|c|c|c|c|c|c|}
\hline \multicolumn{10}{|c|}{$(n=24)$} \\
\hline \multirow{2}{*}{ No. } & \multirow{2}{*}{ Keluhan } & \multirow{2}{*}{\multicolumn{2}{|c|}{ TS }} & \multicolumn{2}{|c|}{ AS } & \multicolumn{2}{|c|}{$\mathrm{S}$} & \multicolumn{2}{|r|}{ SS } \\
\hline & & & $\%$ & & $\%$ & $\mathbf{n}$ & $\%$ & $\mathbf{n}$ & $\%$ \\
\hline 0 & Leher atas & 23 & 95,8 & 0 & 0 & 1 & 4,2 & 0 & 0 \\
\hline 1 & Leher bawah & 24 & 100 & 0 & 0 & 0 & 0 & 0 & 0 \\
\hline 2 & Bahu kin & 14 & 58,3 & 0 & 0 & 10 & 41,7 & 0 & 0 \\
\hline 3 & Bahu kanan & 14 & 58,3 & 0 & 0 & 10 & 41,7 & 0 & 0 \\
\hline 4 & Lengan atas kiri & 23 & 95,8 & 0 & 0 & 1 & 4,2 & 0 & 0 \\
\hline 5 & Punggung & 23 & 95,8 & 0 & 0 & 1 & 4,2 & 0 & 0 \\
\hline 6 & Lengan atas kanan & 23 & 95,8 & 0 & 0 & 1 & 4,2 & 0 & 0 \\
\hline 7 & Pinggang & 6 & 25 & 0 & 0 & 18 & 75 & 0 & 0 \\
\hline 8 & Bokong & 23 & 95,8 & 0 & 0 & 1 & 4,2 & 0 & 0 \\
\hline 9 & Pantat & 23 & 95,8 & 0 & 0 & 1 & 4,2 & 0 & 0 \\
\hline 10 & Siku kin & 13 & 54,2 & 0 & 0 & 11 & 45,8 & 0 & 0 \\
\hline 11 & Siku kanan & 13 & 54,2 & 0 & 0 & 11 & 45,8 & 0 & 0 \\
\hline 12 & Lengan bawah kin & 23 & 95,8 & 0 & 0 & 1 & 4,2 & 0 & 0 \\
\hline 13 & $\begin{array}{l}\text { Lengan bawah } \\
\text { kanan }\end{array}$ & 23 & 95,8 & 0 & 0 & 1 & 4,2 & 0 & 0 \\
\hline 14 & $\begin{array}{l}\text { Pergelangan } \\
\text { tangan kin }\end{array}$ & 15 & 62,5 & 0 & 0 & 9 & 37,5 & 0 & 0 \\
\hline 15 & $\begin{array}{l}\text { Pergelangan } \\
\text { tangan kanan }\end{array}$ & 15 & 62,5 & 0 & 0 & 9 & 37,5 & 0 & 0 \\
\hline 16 & Tangan kin & 24 & 100 & 0 & 0 & 0 & 0 & 0 & 0 \\
\hline 17 & Tangan kanan & 24 & 100 & 0 & 0 & 0 & 0 & 0 & 0 \\
\hline 18 & Paha kin & 24 & 100 & 0 & 0 & 0 & 0 & 0 & 0 \\
\hline 19 & Paha kanan & 24 & 100 & 0 & 0 & 0 & 0 & 0 & 0 \\
\hline 20 & Lutut kin & 17 & 70,8 & 0 & 0 & 7 & 29,2 & 0 & 0 \\
\hline 21 & Lutut kanan & 17 & 70,8 & 0 & 0 & 7 & 29,2 & 0 & 0 \\
\hline 22 & Betis kin & 21 & 87,5 & 0 & 0 & 3 & 12,5 & 0 & 0 \\
\hline 23 & Betis kanan & 21 & 87,5 & 0 & 0 & 3 & 12,5 & 0 & 0 \\
\hline 24 & $\begin{array}{l}\text { Pergelangan kaki } \\
\text { kin }\end{array}$ & 18 & & & & 6 & 25 & & 0 \\
\hline 25 & $\begin{array}{l}\text { Pergelangan kaki } \\
\text { kiri }\end{array}$ & 18 & 75 & 0 & 0 & 6 & 25 & 0 & 0 \\
\hline 26 & Kaki kin & 24 & 100 & 0 & 0 & 0 & 0 & 0 & 0 \\
\hline 27 & Kaki kanan & 24 & 100 & 0 & 0 & 0 & 0 & 0 & 0 \\
\hline
\end{tabular}

Seringnya pekerja jongkok dan duduk membuat betis sering kontraksi. Otot mendapatkan energi dari metabolism aerob dan anaerob dalam bentuk Adenosin Trifosfat (ATP). Jika kontraksi terus menerus dan kebutuhan akan ATP tidak dapat terpenuhi melalui metabolisme aerob, 
Jurnal Ergonomi Indonesia (The Indonesian Journal of Ergonomic)

maka metabolism anaerob menjadi alternatif untuk memenuhi kebutuhan tubuh. Kekurangan dari metabolism anaerob adalah menghasilkan produk yang disebut asam laktat. Asam laktat inilah yang memberikan sensasi nyeri dan pegal.

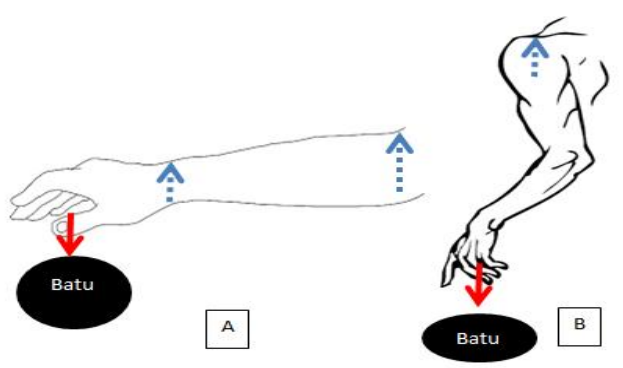

Gambar 4. Ilustrasi Hubungan Beban Batu dengan Nyeri pada Persendian Siku, Tangan, dan Bahu

Keluhan muskuloskeletal pada pemotong batu pada pinggang, lengan atas, bahu, leher atas dan bawah, siku, dan punggung. Pada alat gerak bawah pemotong batu sering mengalami keluhan pada lutut $62,5 \%$, betis $62,5 \%$, pergelangan kaki $50 \%$. Keluhan responden dominan pada siku, pergelangan tangan, dan pinggang untuk bagian tubuh di atas bokong. Sedangkan untuk keluhan otot di bawah bokong dominan sering dirasakan pada lutut dan pergelangan kaki. Beban otot pada pemotong batu dapat diilustrasikan pada Gambar 6.

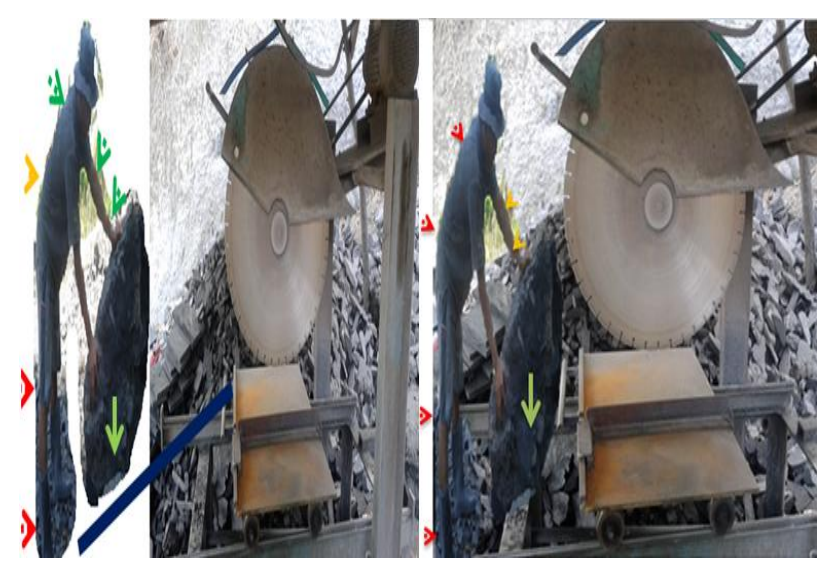

Vol.2, No.1 : 1 Januari-Juni 2016

Gambar 5. Ilustrasi Beban Otot pada Pemotong Batu Saat Mengangkat Batu Langsung dibandingkan dengan Bidang Miring

Tabel 2 Distribusi Frekuensi Keluhan Muskuloskeletal Pemotong Batu Pura Batu Padas $(\mathrm{n}=8)$

\begin{tabular}{|c|c|c|c|c|c|c|c|c|c|}
\hline \multirow{2}{*}{ No. } & \multirow{2}{*}{ Keluhan } & \multicolumn{2}{|c|}{ TS } & \multicolumn{2}{|c|}{ AS } & \multicolumn{2}{|c|}{$\mathrm{S}$} & \multicolumn{2}{|c|}{ SS } \\
\hline & & $\mathbf{N}$ & $\%$ & & $\%$ & $\mathbf{n}$ & $\%$ & $\mathbf{n}$ & $\%$ \\
\hline 0 & Leher atas & 7 & 87,5 & 0 & 0 & 1 & 12,5 & 0 & 0 \\
\hline 1 & Leher bawah & 7 & 87,5 & 0 & 0 & 1 & 12,5 & 0 & 0 \\
\hline 2 & Bahu kiri & 6 & 75 & 0 & 0 & 2 & 25 & 0 & 0 \\
\hline 3 & Bahu kanan & 6 & 75 & 0 & 0 & 2 & 25 & 0 & 0 \\
\hline 4 & Lengan atas kiri & 7 & 87,5 & 0 & 0 & 1 & 12,5 & 0 & 0 \\
\hline 5 & Punggung & 7 & 87,5 & 0 & 0 & 1 & 12,5 & 0 & 0 \\
\hline 6 & Lengan atas kanan & 7 & 87,5 & 0 & 0 & 1 & 12,5 & 0 & 0 \\
\hline 7 & Pinggang & 3 & 37,5 & 0 & 0 & 5 & 62,5 & 0 & 0 \\
\hline 8 & Bokong & 8 & 100 & 0 & 0 & 0 & 0 & 0 & 0 \\
\hline 9 & Pantat & 8 & 100 & 0 & 0 & 0 & 0 & 0 & 0 \\
\hline 10 & Siku kiri & 4 & 50 & 0 & 0 & 4 & 50 & 0 & 0 \\
\hline 11 & Siku kanan & 4 & 50 & 0 & 0 & 4 & 50 & 0 & 0 \\
\hline 12 & Lengan bawah kiri & 8 & 100 & 0 & 0 & 0 & 0 & 0 & 0 \\
\hline 13 & $\begin{array}{l}\text { Lengan bawah } \\
\text { kanan }\end{array}$ & 8 & 100 & 0 & 0 & 0 & 0 & 0 & 0 \\
\hline 14 & $\begin{array}{l}\text { Pergelangan } \\
\text { tangan kiri }\end{array}$ & 2 & 25 & 0 & 0 & 6 & 75 & 0 & 0 \\
\hline 15 & $\begin{array}{l}\text { Pergelangan } \\
\text { tangan kanan }\end{array}$ & 2 & 25 & 0 & 0 & 6 & 75 & 0 & 0 \\
\hline 16 & Tangan kiri & 8 & 100 & 0 & 0 & 0 & 0 & 0 & 0 \\
\hline 17 & Tangan kanan & 8 & 100 & 0 & 0 & 0 & 0 & 0 & 0 \\
\hline 18 & Paha kiri & 8 & 100 & 0 & 0 & 0 & 0 & 0 & 0 \\
\hline 19 & Paha kanan & 8 & 100 & 0 & 0 & 0 & 0 & 0 & 0 \\
\hline 20 & Lutut kiri & 3 & 37,5 & 0 & 0 & 5 & 62,5 & 0 & 0 \\
\hline 21 & Lutut kanan & 3 & 37,5 & 0 & 0 & 5 & 62,5 & 0 & 0 \\
\hline
\end{tabular}

Tabel 2 Distribusi Frekuensi Keluhan Muskuloskeletal Pemotong Batu Pura Batu Padas(n=8) (Lanjutan)

\begin{tabular}{|c|c|c|c|c|c|c|c|c|c|}
\hline 22 & Betis kiri & 3 & 37,5 & 00 & & & 62,5 & 0 & 0 \\
\hline 23 & Betis kanan & 3 & 37,5 & 00 & & & 62,5 & 0 & 0 \\
\hline 24 & $\begin{array}{l}\text { Pergelangan kaki } \\
\text { kiri }\end{array}$ & 4 & 50 & 00 & & & 50 & 0 & 0 \\
\hline 25 & $\begin{array}{l}\text { Pergelangan kaki } \\
\text { kini }\end{array}$ & 4 & 50 & 00 & & & 50 & 0 & 0 \\
\hline 26 & Kaki kini & 8 & 100 & 00 & & & 0 & 0 & 0 \\
\hline 27 & Kaki kanan & 8 & 100 & 00 & & & 0 & 0 & 0 \\
\hline
\end{tabular}

Distribusi keluhan muskuloskeletal pada perakit maupun pemotong batu memiliki pola yang mirip. Keluhan responden dominan pada siku, pergelangan tangan, dan pinggang untuk bagian tubuh di atas bokong. Sedangkan untuk keluhan otot di bawah bokong dominan sering dirasakan pada lutut dan pergelangan kaki. Akan tetapi, pada pemotong batu keluhan pada betis juga merupakan keluhan yang dominan 
Jurnal Ergonomi Indonesia (The Indonesian Journal of Ergonomic)

karena pemotong batu harus berdiri dalam waktu yang lama (Gambar 7).

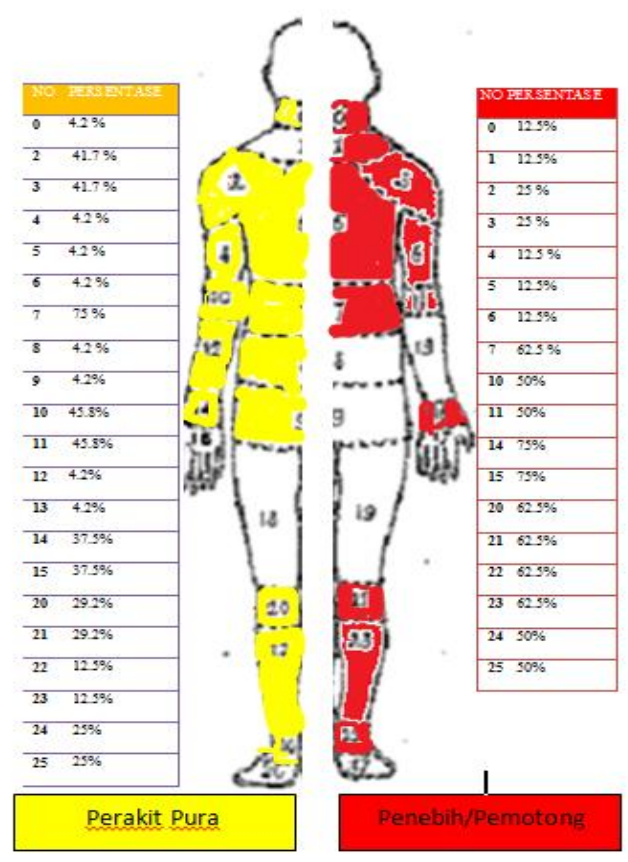

Gambar 6. Persentase Keluhan Otot Pada Perakit dan Pemotong Batu

Keluhan lain pada pekerja seperti pada sistem pernapasan, saraf, dan lain-lain yaitu: pada perakit batu sebanyak 15,6\% responden menyatakan sesak, pada pemotong batu yang hanya 6,25\% dari responden. Keluhan nyeri hidung yang hanya dialami oleh perakit batu sebanyak $3,1 \%$. Hanya pemotong batu yang mengalami keluhan kebas sebanyak 6,25\% responden. Keluhan lainnya seperti kelilipan pada mata dan nyeri pada dada. Keluhan ini dialami hanya pada perakit batu sebanyak $6,25 \%$ responden (Gambar 7).
Vol.2, No.1 : 1 Januari-Juni 2016

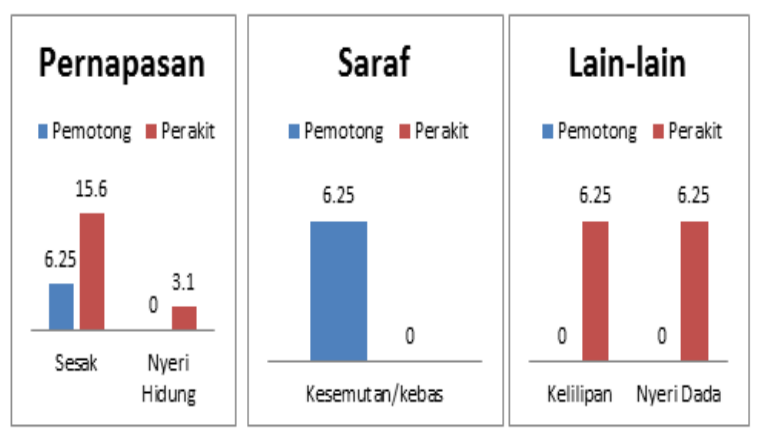

Gambar 7. Grafik Keluhan Lain pada Pekerja Pura Batu Padas

\section{SIMPULAN DAN SARAN}

Berdasarkan hasil penelitian dapat disimpulkan bahwa keluhan muskuloskeletal pada perakit batu sering dirasakan di bagian pinggang $75 \%$, persendian siku kanan dan kiri 45,8\%, bahu kiri dan kanan 41,7\%, dan pergelangan tangan $37,5 \%$. Pada alat gerak bawah sering mengalami keluhan pada bagian lutut $29,2 \%$, betis $12,5 \%$, dan pergelanggan kaki $25 \%$.

Keluhan muskuloskeletal pada pemotong batu pada pinggang, lengan atas, bahu, leher atas dan bawah, siku, dan punggung. Pada alat gerak bawah pemotong batu sering mengalami keluhan pada lutut $62,5 \%$, betis $62,5 \%$, pergelangan kaki $50 \%$.

Keluhan lain pada pekerja seperti pada sistem pernapasan, saraf, dan lain-lain yaitu : pada perakit batu sebanyak 15,6\% responden menyatakan sesak, pada pemotong batu yang hanya $6,25 \%$ dari responden. Keluhan nyeri hidung yang hanya dialami oleh perakit batu sebanyak $3,1 \%$. Hanya pemotong batu yang mengalami keluhan kebas sebanyak 6,25\% responden. Keluhan lainnya seperti kelilipan pada mata dan nyeri pada dada. Keluhan ini dialami hanya pada perakit batu sebanyak $6,25 \%$ responden 


\section{DAFTAR PUSTAKA}

Badan Pusat Statistik Provinsi Bali. 2010. Bali Dalam Angka 2010. Denpasar.

Badan Pusat Statistik Provinsi Bali. 2011. Bali Dalam Angka 2011 Denpasar.

Buchari. 2007. Penyakit Akibat Kerja dan Penyakit Terkait Kerja. USU Repository.

Costa, B. R., Vieira, and Edgar Ramos. 2010. Review Risk Factors for Work-Related Musculoskeletal Disorders: A Systematic Review of Recent Longitudinal Studies. American Journal of Industrial Medicine, $53: 285-323$

Departemen Agama Provinsi Bali. 2011. Pura. Denpasar.

Gannouni, N., Mhamdi, A., El May, M., Tebourbi, O., Ben Rhouma, K. 2014. Morphological Changes of Adrenal Gland and Heart Tissue after Varying Duration of Noise Exposure in Adult Rat. A Bimonthly Inter-disciplinary International Journal.

Indira, I. G. A. N. 2014. Analisis Sikap kerja dengan Tinjauan Health Ergonomic pada Pedagang Canang di Pasar Sanglah. (skripsi). Denpasar: Universitas Udayana.

Indra, A. 2012. Kuat Tekan (Compression Strength) Komposit Lempung/Pasir Pada Aplikasi Bata Merah Daerah Paya Kumbuh Sumbar. Jurnal Teknik Mesin, Vol. 1, No 2, April 2012:10-14.

Kausto, J., Virta, L., Luukkonen, R., and Juntura E.V. 2010. Associations between Partial Sickness Benefit and Disability Pension : Initial Findings of a Finnish Nationwide Register Study. BMC Public Health; $10: 361$.

Maharlika, F. 2010. Tinjauan Bangunan Pura di Indonesia. Jurnal Waca Cipta Ruang, Vol.II No.II tahun 2010/2011 ISSN 23016507.
Makiyah, D. 2007. Makna dan Fungsi Sanggah dalam Agama Hindu, Studi kasus dalam Masyarakat Hindu Jawa. (skripsi). Jakarta: Universitas Islam Negeri Syarif Hidayatullah.

Nejati, P., Lotfian, S., Moezy, A., Nejati, M. 2014. The Relationship of Forward Head Posture and Rounded Shoulders with Neck Pain in Iranian Office Workers. Medical Journal of Islamic Republic of Iran (MJIRI). 